\title{
Analysis of Formative Assessment of Mathematics Subjects During Learning from Home
}

\author{
Intan Rofi'ah ${ }^{1, *}$ Imam Sujadi $^{2}$ Isnandar Slamet ${ }^{3}$ \\ ${ }^{1}$ Postgraduate of Mathematics Education, Faculty of Teacher Training and Education, Universitas Sebelas \\ Maret, Surakarta, Indonesia \\ ${ }^{2}$ Department of Mathematics Education, Universitas Sebelas Maret, Surakarta, Indonesia \\ ${ }^{3}$ Department of Mathematics and Natural Sciences, Universitas Sebelas Maret, Surakarta, Indonesia \\ *Corresponding author. Email: intanrofiah@student.uns.ac.id
}

\begin{abstract}
Learning in the 2013 curriculum is based on competency achievement and build student character. To accomplish these purposes, the learning process must accompany by perfect assessment. The assessment involved assignments and feedback from teacher so students can improve their critical thinking. Formative assessment can be the ideal assessment during learning from home. During the COVID-19, the government implemented the Learning from Home or Belajar dari Rumah (BDR) policy. During the learn from home, learning and assessing mathematics subjects will undoubtedly experience many obstacles. Therefore, this research was conducted to analyse how the formative assessment was carried out in mathematics learning during Learning from home process. This research used a qualitative approach with in-depth interviews with a mathematics teacher at SMA Negeri 8 Surakarta to study formative assessments during learning from home $(B D R)$. In this research, the instruments used were interview guideline with supporting data, such as question archive and the result of student assignment. This research used Miles and Huberman's model to analyse the data with collection of data, data reduction, data presentation, and drawing conclusions or data verification. The result of this research shows that the implementation of formative assessment in SMA Negeri 8 Surakarta during learning from home $(B D R)$ has not been implemented at all.
\end{abstract}

Keywords: Formative assessment, Learning from home (BDR).

\section{INTRODUCTION}

Learning based on the 2013 Curriculum is learning that aims to achieve competence and build student character. The learning process's objectives are included in four core competencies / Kompetensi Inti (KI) based on Permendikbud No. 69 of 2013 concerning the Basic Framework and Curriculum Structure of Senior High Schools / Madrasah Aliyah [1]. The core competency (KI) of the Ministry of Education and Culture clearly shows that the 2013 Curriculum is a character and competency-based curriculum [2]. These competencies can be achieved through the student learning process. Teachers must monitor student learning progress by points $K I 3$ and $K I 4$ to measure the mastering of student competencies [2].

Education is currently being afflicted by the COVID-19, which requires the government to implement the learning from home policy $(B D R)$. Implementation of learn from home $(B D R)$ is carried out online by Surat Edaran No. 4 Tahun 2020 concerning the Implementation of Education in an Emergency for Coronavirus Disease (COVID-19) [3]. During learn from home, learning and assessing mathematics subjects will undoubtedly experience many obstacles.

Students temporarily out of school due to the COVID-19 pandemic, their learning process is impacted in unprecedented ways. Fluctuating from direct classes to online classes is difficult for students, especially those who do not have access to gadgets and internet facilities at their homes or take courses that cannot be conducted online. In addition, students may feel undefined about assessment procedures for online assignments. They will suffer when they do not have 
an internet facility to participate in the evaluation process, adversely affecting their grade averages.

In the teaching and learning process, learning from home is less encouraging in attaining critical thinking skill of students. Teacher usually conduct assessments based on student's learning outcomes; this condition indicates assessment is still limited to practice [16]. The obstacle in this pandemic is learning only takes priority to process understanding without building critical thinking skills of student. The question is how to conduct ideal learning process with ideal assessment in mathematic during COVID-19 pandemic?

Learning process must accompanied with perfect assessment, the assessment must consist of assignment and feedback from teacher so students can improve their critical thinking. Formative assessment can be the perfect assessment in learning from home. Formative assessment involves information given by teachers, especially during daily meetings, which indicate students' internal processing of information, the development of students' understanding, interaction among students, and discussion as a way to discussion ideas [17]. Formative assessment is conducted with the communication process between teachers and students, or between students and students to gain meaningful learning together [18]. Formative assessment can provide effective results in improving learning outcomes [19,20].

Some research related to formative assessment has been led. Most of the research determined that prove the general success of this type of assessment, such as: formative assessment can make students interested in the topics they learned, give motivation, and improve learning outcomes. Formative assessments can improve students' confidence, build intelligent behaviour, and create optimistic feelings [21-23]. In addition, there is also research that settled straight and intuitive feedback on formative assessment is an excellent way to achieve an independent learning process [23]. Feedback can engage students and can improve their learning motivation [24].

In contrast with this research, during learning from home $(B D R)$ carried out by teachers and students, students have not reached their maximum learning outcomes especially in mathematic subject at SMA Negeri 8 Surakarta. During learning, teacher didn't prepare appropriate assessment to accompany learning process so the learning so teacher has not been able to evaluate the students' competencies and monitor students' learning progress. This condition also triggered teachers who can't give feedback optimally and leaves some students in a bad spot where they cannot receive the learning process. As a result of that condition, students can't absorb feedback from their teacher to improve the implementation of learning, and thus students' competencies cannot be achieved marvellously. Through formative assessment, feedback can help teachers make choices about learning that must be carried out at the next learning to help students reach their learning goals and improve their competencies. Some research related to formative assessment can enhance the learning process and student learning outcomes $[25,26]$. Thus, this research is conducted to analyse how the formative assessments carried out in mathematics learning during the learning from home process $(B D R)$. This research findings were made for initial data to analyse how formative assessment can be used during learning from home $(B D R)$.

\section{METHODOLOGY}

This research used a qualitative approach with indepth interview with a mathematics teacher at SMA Negeri 8 Surakarta on formative assessments during learning from home $(B D R)$. Researchers used an instrument in the form of an interview sheet to collect data and information about the implementation of formative assessments conducted by mathematics teachers at SMA Negeri 8 Surakarta. This research also assisted by supporting data in the form of student work and assessment sheets. Researchers used the analysis technique model of Miles and Huberman [4], namely data collection, data reduction, data presentation, and drawing conclusions or data verification. In general, data analysis in this study was carried out in the following stages; (1) record all findings through interviews and rewrite them in the form of an interview transcript; (2) reviewing transcripts of interviews with mathematics teachers and sorting out essential data such as additional information and data such as question files, student work results, and assessment sheets; (3) classify the results of the interview according to the focus on the theme of formative assessment; (4) make the final analysis into conclusions.

\section{RESULT AND DISCUSSION}

The interview results describe the mathematics learning process during learning from process $(B D R)$, which is summarized in Table 1.

During learning from home $(B D R)$ process, the teacher conducts lessons once a week. The math teacher initiated the class by sending a video for one basic competency sent through the WhatsApp group. 
Table 1. Summary of the interview

\begin{tabular}{|l|l|l|}
\hline $\begin{array}{l}\text { Learning from home } \\
(B D R) \text { platform }\end{array}$ & Email, WhatsApp, Quipper, office365 & $\begin{array}{l}\text { Peak internet network, some } \\
\text { students don't have gadget, } \\
\text { expensive internet quota, the } \\
\text { lesson material sometimes didn't } \\
\text { load completely }\end{array}$ \\
\hline $\begin{array}{l}\text { Learning from Home } \\
(B D R) \text { schedule }\end{array}$ & Once a week & - \\
\hline $\begin{array}{l}\text { Type of lesson } \\
\text { material }\end{array}$ & Video, text & $\begin{array}{l}\text { Some students find it was not easy } \\
\text { to use Word }\end{array}$ \\
\hline $\begin{array}{l}\text { The task during } \\
\text { learning from home } \\
B D R\end{array}$ & Make a resume and exercise & $\begin{array}{l}\text { Some students don't do their } \\
\text { homework }\end{array}$ \\
\hline $\begin{array}{l}\text { Accompany during } \\
\text { learning from home } \\
(B D R)\end{array}$ & Discuss on WhatsApp group \\
\hline $\begin{array}{l}\text { Assessment during } \\
B D R\end{array}$ & $\begin{array}{l}\text { Attitude: student activity } \\
\text { Knowledge: Practice questions } \\
\text { Skills: a summary of the material and a } \\
\text { variety of ways to do the practice questions }\end{array}$ & $\begin{array}{l}\text { Some students not involved } \\
\text { student competence }\end{array}$ \\
\hline
\end{tabular}

Students are asked to summarize the video contents into a notebook, which must be collected via WhatsApp one day after the material is given. However, students often ignore the material during learning from home. When the researcher asked the time for collecting student material summaries, the teacher stated that the due of sending summaries was dependent on students' activeness, so not all students gathered material summaries.

Apart from using WhatsApp as the leading platform in learning from home $(B D R)$ process, learning is also carried out through other media such as email, Quipper, and Office 365. The teacher also stated several obstacles during the learning process. As well, teacher did not develop the mathematics lesson plan during learning from home $(B D R)$ and used the lesson plan during the class meeting.

The assessment process conducted during learning from home $(B D R)$ process is different from the assessment during the learning process in class. Assessment is carried out by the teacher on every aspect of competence. For attitude competence, teachers assess students based on activeness. Students are said to be active if they often ask the teacher and collect assignments. For knowledge competencies, the teacher evaluates students based on the assignment. The assignment is done after the students have summarized the material. The assignment is given in a quiz that contained multiple-choice or essay questions. For skills competencies, the teacher evaluates students based on the neatness of the summary writing and the students' creativity to do the problems.

The assessment during the learning from home has not progressed optimally. It can be seen when the teacher has explained the material; the teacher assumes that the students have understood the material. This incident was caused by the teacher can't supervise students directly as in the classroom meeting. The teacher also stated that he did not recognize the students, so learning was only one way. Giving material at the beginning of the lesson, then doing practice questions, and giving marks at the end of the class. Teacher often conducted assessment only based on learning outcomes, and also formative assessment which teacher said has been used is still limited to practice [16].

Through learning from home teacher frequently directed summative assessment only, consequently the assessment only determines students' capacities and achievement of learning objectives. Thus, the outcome 
from this condition students only obtained little feedback because teacher can't give appropriate feedback to students and only assess based on students' learning outcomes. Because of the center of formative assessment is the concept of feedback, in
Based on this characteristic, the implementation of the assessment carried out by teacher does not even approach the low-level characteristic by McMillan. This finding indicates that the assessment is conducted rudimentary because it ignores the characteristics of

Table 2. Variations of formative assessment characteristics by McMillan

\begin{tabular}{|c|c|c|c|}
\hline Characteristic & Low-level Formative & High-level Formative & Findings \\
\hline $\begin{array}{l}\text { Nature } \\
\text { indication }\end{array}$ & $\begin{array}{l}\text { Mostly objective, } \\
\text { standardized }\end{array}$ & $\begin{array}{l}\text { Mixed assessment, consisting } \\
\text { objective, built response, and } \\
\text { anecdotal }\end{array}$ & Standardized \\
\hline Structure & $\begin{array}{l}\text { Typically strict, planned, } \\
\text { anticipated }\end{array}$ & Casual, natural, "at the moment" & Strict \\
\hline Participants & Teachers & Teachers and students & Teacher \\
\hline Feedback & $\begin{array}{l}\text { Mostly late (e.g.,provided quiz } \\
\text { and provide students } \\
\text { feedback by the next day) and } \\
\text { general }\end{array}$ & $\begin{array}{l}\text { Mostly direct and detailed for low } \\
\text { achieving students, late for high } \\
\text { achieving students }\end{array}$ & $\begin{array}{l}\text { The teacher gives } \\
\text { feedback few } \\
\text { days after the } \\
\text { assignment }\end{array}$ \\
\hline When carried out & $\begin{array}{l}\text { Typically after teaching and } \\
\text { assessment (e.g., after a unit) }\end{array}$ & Typically during teaching & After teaching \\
\hline $\begin{array}{l}\text { Instructional } \\
\text { modifications }\end{array}$ & $\begin{array}{l}\text { Mostly rigid, planned (e.g., } \\
\text { pacing according to an } \\
\text { instructional plan) }\end{array}$ & Mostly flexible, unplanned & According to plan \\
\hline $\begin{array}{l}\text { Choice of } \\
\text { instructional } \\
\text { assignment }\end{array}$ & Mostly teacher strongminded & $\begin{array}{l}\text { Teacher and student } \\
\text { strongminded }\end{array}$ & Mostly by teacher \\
\hline $\begin{array}{l}\text { Nature of teacher- } \\
\text { student } \\
\text { communication }\end{array}$ & $\begin{array}{l}\text { Most communications based } \\
\text { primarily on formal roles }\end{array}$ & $\begin{array}{l}\text { Wide-ranging, informal, gullible, } \\
\text { and honest interactions }\end{array}$ & $\begin{array}{l}\text { Mostly formal } \\
\text { interaction }\end{array}$ \\
\hline $\begin{array}{l}\text { Role of student } \\
\text { self-evaluation }\end{array}$ & Little or nothing & Integral & Little \\
\hline Form of motivation & $\begin{array}{l}\text { Typically extrinsic (e.g., } \\
\text { passing a competency test) }\end{array}$ & Typically intrinsic & Extrinsic \\
\hline $\begin{array}{l}\text { Acknowledgment } \\
\text { for achievement }\end{array}$ & $\begin{array}{l}\text { External factors (teacher; } \\
\text { luck) }\end{array}$ & $\begin{array}{l}\text { Internal, unstable factors (e.g., } \\
\text { moderate student effort) }\end{array}$ & External factor \\
\hline
\end{tabular}

this condition students often found misconceptions, lack of understanding, and less encouraging during learning from home.

This condition is contrary with the impact of formative assessment arises from the strength of the feedback given to students about their learning and to the teacher about how they teach [6]. The verbal feedback will provide students a clear, detailed, and personal explanation about the task they have worked [7]. In gathering this information, teachers and students need to conduct formative assessments. formative and incomplete assessments.

The following is an analysis of formative assessment conducted by SMA Negeri 8 Surakarta in mathematics learning during learning from home $(B D R)$ based on variations of formative assessment characteristics by McMillan in Table 2 [8].

Providing feedback from formative assessments has an impact on student achievement targets [9]. There are two types of achievement targets, namely performance goals and mastery goals. Performance 
goal orientation focuses on comparing the abilities of each student. The teacher evaluates simultaneously and rewards students whose achievements exceed other students. This theory is appropriate with the findings in Table 2, where the mathematics teacher giving feedback at SMA Negeri 8 Surakarta is carried out a few days after the assignment is submitted. The feedback is in the form of an answer key from the question exercise. This condition is opposite to mastery goals oriented towards understanding, mastering new competencies, and dare to take on challenges. The teacher evaluates based on each student's progress to provide opportunities for students to develop, see mistakes as part of learning, and the teacher evaluates students personally [10] [11] [12]. Typical students with a performance goal orientation tend to procrastinate and show a habit of cheating [11]. This incident also happened to students at SMA Negeri 8 , such as procrastinating, some students even did not collect the assignment at all or changed names on other students' answer sheets.

Teachers must also design well-planned assessments, for example, in the written lesson plan (RPP). Following Budiyono's statement, namely that the teacher actually has done AfL when they have made a formative assessment and made feedback at the learning process stage, even though this was done informally and was not well planned (not written in the lesson plan) [5].

In contrast to low-level formative, high-level formative has an impact on student learning motivation. Learning motivation is needed as an encouragement for students to achieve learning goals. Growing motivation can be influenced by several factors, one of them is through an effective assessment [9]. The implementation of the assessment at SMA Negeri 8 Surakarta cannot be categorized as maximum because it does not impact students' motivation during learning from home $(B D R)$. SMA Negeri 8 Surakarta students' motivation is extrinsic to teacher-centered learning, so that the teacher plays a significant role in motivating students during the learning process. This finding is not in line with the research conducted by Budiyono (2010), which concluded that the formative assessment-based learning model (AfL) could increase the effectiveness of learning mathematics [13].

\section{CONCLUSION}

This research indicates that the implementation of formative assessment in SMA Negeri 8 Surakarta during learning from home $(B D R)$ has not been implemented at all. This can be seen from the implementation of formative assessments that are not well planned by mathematics teachers and still limited to practice. The teacher only assesses at the end of the learning (summative) caused student competence, and learning quality are not monitored during learning from home $(B D R)$ process.

Based on the variations of formative assessment characteristics by McMillan, the implementation of the assessment carried out by teacher does not even approach the low-level characteristic because it ignores the characteristics of formative assessment. Giving feedback affects student achievement targets where students of SMA Negeri 8 Surakarta are oriented towards performance goals. Implementation of formative assessment has not had an impact on student motivation because learning is teachercantered.

From the results of the analysis conducted by researchers, it is necessary to develop a formative assessment model that can be used in learning from home $(B D R)$ process. The formative assessment that is carried out must be well planned, can monitor the development of student competencies during learning from home $(B D R)$, the feedback can be used by teachers and students, and includes high-level formative so that teachers and students' involvement can contribute to formative assessment optimally. Student involvement in self-evaluation also needs to be done so students can understand what the teacher is expecting. Students can get a clear picture and learning targets so that formative assessments can help students get sensitivity and achievement targets based on their work [14][15].

\section{ACKNOWLEDGMENTS}

The authors would thank people who give support to improve this research. Moreover, the author would also show gratitude for SMA Negeri 8 Surakarta's math teacher, who provides the author with a chance to observe and study more about formative assessment.

\section{REFERENCES}

[1] Peraturan Menteri Pendidikan dan Kebudayaan Nomor 69 Tahun 2013 Tentang Kerangka Dasar dan Struktur Kurikulum Sekolah Menengah Atas/Madrasah Aliyah.

[2] Mulyasa E. The Development and Implementation of Curriculum 2013. Bandung: Remaja Rosdakarya; 2013. 
[3] Surat Edaran No. 4 Tahun 2020 Tentang Pelaksanaan Pendidikan dalam Masa Darurat Coronavirus Disease (COVID-19).

[4] Miles MB, Huberman AM, Saldana J. Qualitative data analysis: a methods sourcebook third edition. USA: Arizona State University; 2014.

[5] Budiyono, Mardiyana. Assessment for Learning dan Assessment as Learning. Surakarta: UNS Press; 2019.

[6] Ozan, Ceyhun \& Kincal, Remzi. The Effects of Formative Assessment on Academic Achievement, Attitudes toward the Lesson, and Self-Regulation Skills. Educational Sciences: Theory \& Practice, 2018, pp. 85-118.

[7] Voelkel S, Mello L. Audio Feedback - Better Feedback?, Bioscience Education, 2014, pp. 1726.

[8] McMillan JH. Classroom Assessment: Principles and Practice for Effective Instruction, 3rd Edition. Boston: Pearson; 2004.

[9] Cauley KM, McMillan JH. Formative Assessment Techniques to Support Student Motivation and Achievement. Clear House A J Educ Strateg Issues Ideas, 2010, 83(1):1-6.

[10] Patrick H, Anderman LH, Ryan AM, Edelin KC, Midgley C. Teachers' communication of goal orientations in four fifth-grade classrooms. Elem Sch J, 2001, 102(1):35-58.

[11] Meece JL, Anderman EM, Anderman LH. Classroom goal structure, student motivation, and academic achievement. Annu Rev Psychol, 2006, 57:487-503.

[12] Ames C. Classrooms: Goals, structures, and student motivation. J Educ Psychol, 1992, 84(3):261-71.

[13] Budiyono. Peran Asesmen dalam Peningkatan Kualitas Pembelajaran. Surakarta; 2010. (Seminar Nasional Pendidikan Matematika).

[14] Bruce LB. Student self-assessment: Making standards come alive. Classr Leadersh, 2001, $5(1): 1-6$

[15] Stiggins RJ. From formative assessment to assessment for learning: A path to success in standards-based schools. Phi Delta Kappa, 2005, 87(4):324-8.

[16] Sriyati, Siti. Peran Asesmen Formatif Dalam Membentuk Habits of Mind Mahasiswa.
Pascasarjana Universitas Pendidikan Indonesia Bandung, 2010.

[17] Ronnis D. Asesmen Sesuai Cara Kerja Otak. Jakarta: Indeks; 2011.

[18] Lee hang, D.M. and B. Bell. 2015. Written formative assessment and silence in the classroom. Cult Stud of Sci Educ, 2015.

[19] Noblitt, L \& Vance, D \& Smith, M. A Comparison of Case Study and Traditional Teaching Methods for Improvement of Oral Communication and Critical-Thinking Skills. Journal of College Science Teaching, 2010.

[20] Williams AE, Aguilar-Roca NM, Tsai M, Wong M, Beaupré MM, O'Dowd DK. Assessment of Learning Gains Associated with Independent Exam Analysis in Introductory Biology. CBELife Sciences Education, 2011.

[21] Sriyati, S., Rustaman, N., \& Zainul, A. Kontribusi Asesmen Formatif Terhadap Habits of Mind Mahasiswa Biologi. Jurnal Pengajaran MIPA, 2010.

[22] Katharine, S, Jennifer K. Knight, Gülnur Birol, and Michelle K. Smith. The Colorado Learning Attitudes about Science Survey (CLASS) for Use in Biology. CBE-Life Science Education, 2017.

[23] Saptono, S., Rustaman, N.Y. Model Integrasi Atribut Asesmen Formatif (IAAF) dalam Pembelajaran Biologi Sel untuk Mengembangkan Kemampuan Penalaran dan Berpikir Analitik Mahasiswa Calon Guru. Jurnal Pendidikan IPA Indonesia, 2017.

[24] Crisp, V \& Ward, C. The development of a formative scenario-based computer assisted assessment tool in psychology for teachers: The PePCAA project. Computers \& Education, 2008.

[25] Bernard B, Matti T, Uno F, Evode M. Exploring Feedback Practices in Formative Assessment in Rwandan Higher Education: A multifaceted approach is needed. International Journal of Teaching and Education, 2016.

[26] Le Thai, Hung \& Ha, Le \& Thu, Le. Applying Formative Assessment Techniques to Promote Students' Learning Outcomes and Interest. ICREAM, 2018. 